Yayınlayan: Ankara Üniversitesi KASAUM

Adres: Kadın Sorunları Araştırma ve Uygulama Merkezi, Cebeci 06590 Ankara

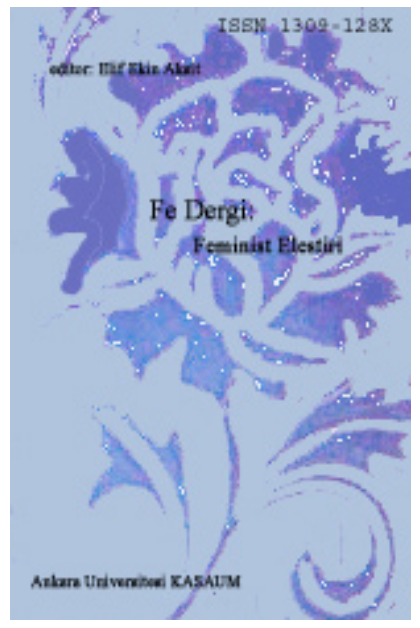

Fe Dergi: Feminist Eleştiri 13, Sayı 2

Erişim bilgileri, makale sunumu ve ayrıntılar için:

http://cins.ankara.edu.tr/

Hassas Gruplarla Sahada Çalş̧mak: Şehit Anneleri ile Görüş̧me Deneyimleri

Esra Gedik

Çevrimiçi yayına başlama tarihi: 15 Aralık 2021

Yazı Gönderim Tarihi: 09.04.2020

Yazı Kabul Tarihi: 09.09.2021

Bu makaleyi alıntılamak için: Esra Gedik, "Hassas Gruplarla Sahada Çalışmak: Şehit Anneleri ile Görüşme Deneyimleri” Fe Dergi 14, no. 2 (2021), 102-112.

URL: http://cins.ankara.edu.tr/26_9.pdf

$\mathrm{Bu}$ eser akademik faaliyetlerde ve referans verilerek kullanılabilir. Hiçbir şekilde izin alınmaksızın çoğaltılamaz. 


\section{Hassas Gruplarla Sahada Çalışmak: Şehit Anneleri ile Görüşme Deneyimleri Esra Gedik*}

Bu çalışmada amacım saha çalışması sırasında karşılaştı̆̆ım sorunlar ve araştırmam sırasında ve sonrasında edindiğim deneyimler ışı̆̆ında kadın bir araştırmacı olarak hassas gruplarla alan araştırması nasıl yapılır göstermektir. Bu amaçla yüksek lisans tez araştırmam için görüşme yaptı̆̆ım "şehit anneleri" ile olan deneyimlerimi farklı başlıklar altında toplayarak analiz ettim. Bu analiz sonucunda içerlikli ve dişarlıklı olmak konumlarının sabit konumlar olmadı̆̆ını, araştırmanın gidişatına göre sürekli değişebileceğini, erkek yoğun ortamlarda kadın bir araştırmacı olarak araştıran ile araştırılan arasındaki güç ilişkilerinin nasıl kurulduğunu, araştırılan ve araştırmacı arasında güven ilişkisi kurmanın alan araştırması için en önemli unsur olduğunu kanıtlamaya çalıştım ve duygusal olarak yoğun geçen görüşmelerde araştırmacının kendini yeniden konumlandırmak için yapması gerekenlerin ne olduğunu gösterdim.

Anahtar Kelimeler: Saha araştırması, feminist yöntem, hassas gruplar, şehit anneleri.

\section{Working in the Field with Sensitive Groups: Meeting Experiences with the Mothers of the Martyrs}

In this study, I aim to show how to conduct field research with sensitive groups as a female researcher in the light of the problems I encountered during the field study and the experiences I gained during and after my research. For this purpose, I gathered and analyzed my experiences with "Marty mothers" that I interviewed for my master thesis research under different headings. As a result of this analysis, I tried to prove that being inclusive and externality is not fixed positions, it can change constantly depending on the process of the research, how power relations are established between the researcher and the researched as a female researcher in male intensive environments, and establishing a trust relationship between the researcher and the researched is the most important factor for field research and in the emotionally intense conversations, I showed what the researcher had to do to reposition himself.

Keywords: Field research, feminist method, sensitive groups, martyrs' mothers.

\section{Giriş}

Son iki yıldır lisans üçüncü sınıf öğrencilerine "Saha Araştırmaları ve Uygulamaları” dersini veriyorum. $\mathrm{Bu}$ ders kapsamında saha çalışması sırasında nelere dikkat edilmeli, neler ile karşılaşılabilir, sorunlarla nasıl baş edilir bu konuda bilgilendirme yapıyorum. Ders anlatırken öğrencilerin hem dikkatini çekebilmek hem de olası sorunlara örnek olması için yüksek lisans ve doktora tez çalışmalarımın saha çalışması sırasında yaşadıklarımdan bahsediyorum. Bunları yaparken fark ettim ki sahada "hassas gruplarla" nasıl çalışılır konusunda yazılı çalışmalar çok az. Bu nedenle, bu makalede, "Ideological Ambivalence of Motherhood In The Case of Mothers of Martyrs in Turkey" (Anneliğin İdeolojik Muğlaklığı Türkiye'de Şehit Anneleri Örneği) başlıklı yüksek lisans tez alan araştırmasında karşılaştığım zorlukları ve baş etme yöntemlerini anlatmayı amaçlıyorum. Kendi alan deneyimimi anlatmaya çalışacağım bu çalışmada, cevabını aradığım soru, alan araştırması sırasında şehit anneleri gibi travmatik durumları yaşamış görüşmecilerle alan çalışması nasıl yürütülür? Şehit anneleri ${ }^{1}$ ile çalışmanın zorluklarını ve baş etme yollarını anlatmadan önce Türkiye'de şehit anneliğini anlamamız gerekli. Ondan sonra şehit annelerine neden "hassas grup" dediğim açıklığa kavuşmuş olacaktır.

Ramazanoğlu'na (1998, s.90) göre kadınların toplumda kadın olarak görülmelerinin başlıca sebebi doğurabilmeleridir. Bu nedenle, toplumda kadınlara bu yeteneklerinden dolayı verilmiş en önemli rollerden biri anneliktir. Sara Ruddick (1980) kadınların anne olarak tanımlanmasının “anneliğe özgü düşünme biçimi”ni yarattığını dile getirir. Bu rol, küçük yaşlardan itibaren kız çocuklarına öğretilir. Örneğin, kız çocuklarına bebekler alınır, bebeğe bakım oyunları oynanır. Doğurmak, doğurduğu ile ilgilenmek ve korumak bu anlamda annelik pratiklerindendir.

Buna karşılık, anneliğe özgü düşünme biçimi ve "annelik pratiğì" ile savaş pratikleri arasındaki bağları daha yakından incelemeliyiz. Toplumsal cinsiyet ve barış siyaseti arasında bir ilişki olduğu düşünülür. Bu minvalde, erkekler savaşçı kabul edilirken, kadınlar, özellikle doğurganlıkları nedeni ile barışın temsilcisi

\footnotetext{
*Yozgat Bozok Üniversitesi Sosyoloji Bölümü, Doç. Dr., ORCID 0000-0003-3192-2107.
} 
olarak farz edilir. Ruddick, anneliğe yakışan barışı korumanın sembolü olarak, acılı annenin güçlü imgesini hatırlatır. Scheper-Hughes (2008, s.33) annelerin savaş durumlarında sembol olarak kullanılmasını şu şekilde yorumlar: "Acı çeken, kahrolan anne, oğlunun cansız bedeni üzerinde ağlar ve hayatta kalanlara hastabakıcılık etmek, evleri yeniden yapmak ve savaşların yok ettiği toplumsal bağları yeniden örmek için ayakta kalır."

Dünyanın pek çok yerinde anneler hem savaşın sembolleri hem de savaş karşıtlığı için politik söylemlerin parçaları olmuşlardır. Örneğin, Latin Amerika'daki anneler, Türkiye'de oğlunu askerde kaybeden “şehit anneleri”, Barış Anneleri, Diyarbakır'da nöbet tutan anneler, Cumartesi Anneleri, vb. Aslan (2008, s. 67) bu durumu şöyle ifade eder:

Anne-çocuk analojisi üzerinden bir kamusal annelik söylemi kurulmuştur. Kadınların ortak kimliği olarak annelik onlara ahlaki bir sorumluluk vermektedir ve annelik, kadınlar arasındaki tüm bölünmeleri ortadan kaldıracak, sınıflar ve kimlikler üstü bir kimlik olarak sunulmaktadır.

90’larla birlikte PKK ile Türkiye arasındaki silahlı çatışmalar sonrasında silahlı çatışmada oğullarını kaybeden ve "şehit annesi" olarak adlandırılmaya başlanan kadınlar kamusal alanda görünür olmaya başlamışlardır. $\mathrm{Bu}$ anneler oğullarını askerlik hizmetini tamamlayıp dönmelerini beklerken, beklenmedik bir ölümle karşılaşıyorlar ve bundan sonraki yaşamlarını Sancar'ın ifade ettiği gibi "psikolojik olarak sakat" devam ediyorlar (Sancar, 2001). Bu açıdan incelendiklerinde, evlatlarını trafik kazasında kaybeden annelerden daha farklı bir durumla karşı karşıya kalıyorlar. Oğullarının neden vefat ettiğini kendilerine açıklayamıyorlar. Bu noktada, Türkiye'deki şehitlik söylemi ölümü anlamlandırmak için devreye giriyor. Tez çalışmam sırasında görüştüğüm anneler şehitlik söylemi içerisinde yeni bir anlam dünyası oluşturduklarını dile getirmişlerdi ve şehitlik kavramı bu anneler için "sevdikleri insanın kaybını anlamlandırmaya ve sonrasında yaşanan acıyı katlanılabilir k1lmaya" yarıyor (Gedik, 2009a, s. 33). ${ }^{2}$

Şehitlik söyleminin temelde Türkiye'de oğlunu silahlı çatışmada kaybeden bu kadınlar için iki önemi var. Gedik (2009a) bu durumu şöyle özetliyor:

Birincisi şehitlik dinen kutsanmış, yüceltilmiş ve önemli bir olaydır ve şehit olanın hem kendisinin hem ailesinin dinen ödüllendirildiğine inanılır. Tanrı tarafından cennetle mükâfatlandırılacaklarına inanılır. Oğullarının sahip olduğu bu kutsallık onların şehitliği ile annelere, ailesine, geçiyor ve onları Tanrının önünde saygın bir konuma getiriyor. İkinci sonucu ise şehit olmak yalnızca dinen kutsanan bir olay değil aynı zamanda sosyal bir saygınlık kazandırıyor. Şehitlikle kazanılan saygınlık sadece din ile sınırlı değildir. Bunun ayrıca toplumsal bir boyutu da bulunmakta. "Vatan uğruna ölmek" askerler tarafindan elde edilebilecek en yüksek mertebelerden biridir.

Bu durum şehit annelerini iki konumdan hassas bir grup yapıyor. Oğullarının vefatı sonrasında yas dönemi şehitlik söylemi nedeni ile hiç son bulmayan travmatik bir grup olmalarından dolayı. Artı herhangi bir ölümden farklı olarak kutsanan bir ölümün saygınlığının getirdiği sorumluluklar ve devlet tarafından sağlanan hakların kaybı korkusu ${ }^{3}$ nedeni ile bu gruplarla çalışmak zorludur.

\section{Yöntem}

Tez çalışmamın saha araştırmasında temel olarak kullandığım yöntem derinlemesine görüşme tekniği idi. Sonuç olarak on dört şehit annesi ve yedi şehit babası olmak üzere, ortalama bir buçuk saat süren ve kayıt dişı tutulan konuşmaların bu süreyi bile aştığı, toplam yirmi bir görüşme yaptım. Saha çalışmamı feminist bir yöntem kullanarak gerçekleştirdim.

Bir araştırmayı neyin feminist bir araştırma yaptı̆̆ına dair standart bir uzlaşma yok. Araştırmacılar arasında çeşitlilik var. Brooks ve Hesse-Biber'e (2007) göre, araştırma, devam eden bir dizi karar ve seçenek içeren bir süreçtir. Bir araştırmayı feminist araştırma yapan şey, araştırmanın konusuna karar vermekten verilerin incelenmesi ve analizine kadar feminist vizyon içinde yapılandırılmış olmasıdır (Cook ve Fonow, 2007). Hesse-Biber (2011) göre feminist araştırmanın farklı disiplinlerde androcentric yaklaşımları incelemek, eleştirmek ve bu disiplinlerde toplumsal cinsiyeti bir analiz kategorisi olarak dahil etmeyi amaçlamaktadır. Feminist araştırma sadece kadınların yaşamlarını ve deneyimlerini incelemek için değil aynı zamanda aktif olarak onları ilerletmektir. $\mathrm{Bu}$ görüş genellikle, araştırma kadınlar için yapılır, sadece kadınlar üzerinde/hakkında değil (Harding, 1987) şeklinde diye ifade edilir. Feminizm ve Metodoloji kitabında Sandra Harding (1987, s. 1) "ayırt edici feminist araştırma yöntemi” olduğu fikrini reddediyor. Harding (1987,s. 6) "Feminist araştırmanın en aydınlatıcı özellikleri nelerdir?" diye sorar ve üç unsurdan bahseder. Birincisi, feminist araştırma problemini kadın deneyimleri açısından inceler. İkincisi, feminist araştırma kadınların “istediği ve ihtiyaç duyduğu” yolları arar. Son olarak, feminist araştırma "araştırmacıyı araştırılan ile aynı kritik 
düzlemde bulur" (Harding, 1987, s.8). Hesse-Biber (2007:, ss. 16-17) Feminist Araştırma El Kitabı adlı çalışmasında feminist araştırmaları "baskın araştırma çalışmalarında cinsiyet ön yargılarını düzeltmenin ötesine geçmek" olarak tanımlamaktadır. Harding (1987), Mary Margaret Fonow ve Judith A. Cook (1991) ile benzer şekilde, Hesse-Biber (2007) araştırmada güç ve refleksivite konularına odaklanmaktadır. Feminist bir araştırmada, araştıran ile araştırılan arasında hiyerarşik ilişkiler yoktur. Ana tartışma konusu feminist araştırmanın, araştırmaya sadece kadınları eklemekten daha fazlası olduğu yönündedir.

Feminist araştırma iki şey açısından önemlidir: araştırmanın nasıl olduğu ve araştırma ile neler yapılır. Feminizme farklı yaklaşımlarına dayanarak, feminist araştırmacılar farklı yöntemler kurabilir, kullanabilir ve kadınları incelemek için farklı teknikleri tercih edebilir. Başka bir deyişle, Landman (2006, s. 430) diyor ki feminist yöntem, toplumsal yaşam hakkında üretilen bilginin, erkeklerin egemen olduğu ve toplumsal yaşamın cinsiyetçi doğasını dikkate almayan herhangi bir yöntem bağlamında kadınların sosyal gerçeklikleri ile nasıl ilișkilendirilip birleștirilemeyeceği ile ilgilidir. Harding ve Reinharz'ın tartıșmalarına dayanan Hekman, feminist araştırmalarda var olan bir dizi ortak tema olduğunu söylüyor. Standart anketler, istatistiksel hesaplamalar, istatistiksel bilgiler de kadınların ve erkeklerin farklı pozisyonlarına ilişkin konuları resmetmek için kullanılır. Feminist yöntem, araştırmacının ve araştırılanın kişisel yaşamlarını ve deneyimlerini araştırmanın bir parçası olarak görmektedir (Naples, 2007). Bu nedenle, feminist yöntem, araştırmacıya verileri değerlendirme ve yazma sürecinde kendi kendine düşünen (self reflexive) bir yer açmaktadır. Bu vurgulanan yönler araştırmacının kadınların deneyimlerinin çeşitli yönlerini eleştirel olarak araştırmasını ve dönüştürmesini sağlar. Sonuç olarak, feminist araştırmanın özellikleri, kadınların deneyimlerine odaklanma, inceleme cinsiyet ve refleksivite, kadınların çalışılmasında önemli yollardır.

\section{Feminist Etnografi}

Etnografi, insanlar hakkında yazmak anlamına gelir (ethos: insanlar, ırk veya kültürel grup ve grafik: yazma, sunum) (Neuman, 2003). Etnografi, araştırmacı tarafından doğal ortamdaki sosyal ve sıradan etkinliklere doğrudan katılarak gerçekleștirilen sahada veri toplama süreci olarak da tanımlanabilir (Brewer, 2000: 6). Etnografi bir yöntem olarak alan temelli, kişisel, çok faktörlü, boylamsal, tümevarımsal, diyalog temelli ve bütünseldir (Angrosino, 2007). 


\section{Saha Deneyimleri}

\subsection{Alanı Bulmak}

Başarılı bir alan araştırmasının zamanında tamamlanması genellikle büyük ölçüde dışarıdaki faktörlere bağlıdır: Araştırmacının yeterli fonlamaya, zamana ve yeterli desteğe sahip olup olmadığına, güncel bir konunun yanı sıra araştırmaya katılmak isteyen bir topluluk bulmak başarı için minimum ön koşuldur. Başka bir deyişle alanı bulmak önemlidir. Şehit anneleri, göçmenler, cinsel istismar gibi konularda alan araştırması yapmanın en önemli başarısı "doğru” alanı bulmaktır.

Pozitivist sosyal bilimler, araştırmacının, araştırdığı konu ve kişilerle arasına mesafe koymasını ve kendisini değerlerden yalıtması gerektiğini; ancak bu yolla objektivitenin sağlanabileceğini öne sürer (Ramazanoğlu ve Holland, 2002). Öte yandan feminist yöntem araştırmacı ile araştırılan arasında mesafe koymak yerine araştırmacıyı da araştırmanın içinde konumlandırmaya çalışır (Oakley; 1981). Çünkü araştırmacının konumsallığını belirleyen unsurlar göz önüne alındığında araştırmacının sahaya herhangi müdahalede bulunmaması ve sahayı etkilememesi mümkün değildir (Davies, 2008, s. 4). Feminist yöntem, bilgi üretirken, araştırmacı ve görüşülenler arasında mümkün olduğunca eşit bir ilişki olmasını önerir. Araştırmacı, sahada değişmez tek bir konuma sahip değildir. Araştırmacının bir saha çalışmasında karşılaştığı her kişi, girdiği her ortam veya deneyimlediği her bir olayda farklı konumları olması muhtemeldir (Krilić, 2011; Narayan, 1993).

23 yıl boyunca babamın mesleği gereği askeri alanların içinde, askeri unsurlar ile birlikte yaşadım ancak bir kere bile karşılaşmadığım şehit anneleri ile ODTÜ Siyaset Bilimi ve Kamu Yönetimi bölümünde yüksek lisans yaparken tezimin alan araştırması için karşılaştım. Yüksek lisans yaptığım sıralarda medyada yoğun bir şekilde "vatan sağ olsun demiyorum" şeklinde beyan veren asker anneleri görülmeye başlanmıştı. Ben de bu nedenle militarizm, annelik, kadınlık, ölüm ve şehitlik ile ilgili ilişkileri incelemek için şehit annelerini alan araştırması yapmak için belirlemiştim. Daha önce hiç alan araştırması yapmamış biri olarak alan araştırmasının taslağını çıkarmak, neler yapabileceğimi, sınırlarımı, şehit annelerine nasıl ulaşacağımı anlamaya çalışmak çok zordu.

Alan araştırması sırasında araştırmacının konumu, araştırmacının alanı bulması hususunda etkilidir. Bir saha çalışması ortamında, araştırmacıların cinsiyet, etnik köken ve sınıf ile diğer ilişkiler arasında yer alabilecek konum ve ayrıcalık farklılıklarının araştırmayı ve araştırmacı-araştırılan ilişkisini nasıl etkilediğini bilmek gerekir (McCorkel ve Myers, 2003). İçinde yetişilen sosyal hayatın araştırmacıyı "içeriden" veya "dışarıdan” olarak tanımlandığı araştırmacı konumları yaratmaktadır. Aynı zamanda, alanda araştırmacı alışık olmadığı toplumsal kesimler tarafindan kabul görebilir. Bu da sık rastlanan bir durumdur. ODTÜ'de okuyan bir asker kızı olarak, bu kimlik kavşaklarında çeşitli kimliklerin söylemsel olarak alanı nasıl etkileyeceğini bilmiyordum. Bu kimliklerin alandaki güç ve konumsallık üzerindeki etkilerini alana çıkmadan bilmiyordum. Bu açıdan, alan araştırmamı planlamak, birden fazla değişkenin türlü kombinasyonlarını göz önünde tutmaya çalışarak bir seri karar vermemi gerektirdi.

İçerlikli veya dışarlıklı olarak sahaya girebilmek kadar önemli diğer konular ise, sahada kalabilmek ve çalışmanın gerektirdiği sayıda/nitelikte katılımcıyla görüşmek; katılımcıların bekar bir kadın olarak benimle oldukça kişisel konularda konuşmalarını sağlamak ve bu sırada da olası risklerden kaçınmak üzere stratejiler geliştirmek oldukça zordu. Araştırmanın konusunu seçebilmek, alana ve sonrasındaki sürece bakıldığında en kolay olan kısımdı. Karşılaştığım ilk zorluk, araştırmacılara ulaşmak idi. Şehit annelerine nassıl ulaşacağıma dair bir fikrim yoktu. Tüm heyecanım ve tedirginliğimle ilk işim şehit annelerine ulaşmaktı. Bu amaçla emekli asker olan babamın sosyal dayanışma ağlarından faydalandım. Hem rütbesinden hem de yaşından dolayı çevresi babama büyük saygı gösterir. Çalışmamın başında şehit annelerine ulaşmam babamın askeriyedeki görevlilere bu saygınlığı da kullanarak "bizim kızın bir ödevi var, gelse yardımcı olur musunuz?" diye sorması ile oldu. Babamın askeriye ile olan bağı beni Şehit Aileleri Federasyon'larına yönlendirdi.

\subsection{Erkek Yoğun Alanlarda Kadın Araştırmacı Olmak}

Başlangıçta Şehit Aileleri Federasyonu'ndan anneleri seçtim (ŞAF) deneyimleri ve başkalarının deneyimleri hakkında konuşabilir diye. Bunun için üç haftada bir veya iki kez organizasyona gittim. Federasyon her ne kadar şehit aileleri adına kurulmuş olsa da içeri adımınızı atar atmaz mekanın eril bir alan olduğunu anlıyorsunuz. Türkiye'de kadınların siyaset yapma pratiklerine baktığımızda şehit ailelerinin hakları 
ve yaşamlarının savunulması ile ilgili bir kurumun kadınlardan, özellikle yaşı ilerlemiş kadınlardan, oluşmaması şaşırtıcı değildi. ${ }^{4}$

Feminist araştırma yöntemleri saha çalışması literatüründe toplumsal cinsiyetin görmezden gelindiği belirtir (Hollway ve Jefferson 2000). Sahaya giriş her zaman zordur ve toplumsal cinsiyetleri nedeniyle kadınlara özgül sorunlar ortaya çıkabilir. Araştırmacının kadın, araştırılanın erkek olduğu durumda Lee'nin (1990) belirttiği üzere kırılgan bir alan oluşabilir. Çünkü alan yalnızca karşıt cinsiyetlerin bir araya gelmesi değil aynı zamanda toplumsal cinsiyet algılarının da çarpıştığı bir yer haline gelir. Gurney (1985) ve Arendell (1997) erkek görüşmecilerin cinsiyetçi tavırlarından bahsederler. Kadın araştırmacı, eğer yaşı da genç ise daha fazla cinsiyetçi müdahaleye maruz kalmaktadır. "Geleneksel kadın" rollerine uygun olarak kadın araştırmacılardan "naif ve zararsız" olmaları beklenir. Bu nedenle, özellikle mekan içerisinde gözlem yaparken, davranışlarımın, giyimimin nasıl olacağı, mekan içerisinde kendimi hangi yönde temsil edeceğimin makullüğü, yapacağım araştırmanın sınırları ve özgünlüğü açısından da oldukça önemli idi. Başlarda bu kadar erkek yoğun bir mekanda bulunmayı bir dezavantaj olarak düşünsem de bu “zararsız"lık hali bir avantaja dönüştü. Erkek yoğun o mekanda bulunmam üyeler tarafindan garipsenmedi.

Araştırmacının konumunun belirtilmesi, bilginin hangi ortamlarda üretildiği hakkında net bir fotoğraf sunduğu için bilginin güvenirliğini de sağlamaktadır. Bu nedenle, ben de araştırmaya başlarken, orta sınıf asker ailesinde büyümüş bekâr bir kadın olduğumu dernekteki görüşmelerime başlarken belirttim. Kabul ediyorum bir askerin kızı olarak statümün beyanı muhtemelen bana organizasyonda annelere ulaşmak için erişim sağladı. Muhtemelen bir askerin kızı olmak olarak içerlikli konumum onlarla ve annelerle konuşmama izin vermeleri için güvenilir bir ortam sağladı. Oğuz'un (2012, s. 71) çalışmasında kadın araştırmacı ve erkekler ile olan ilişkiyi şöyle açıklar:

Erkeklerle de aramda sınıfsal ve etnik farklılık vardı ama belki de cinsiyet farklılığının apaçık ortada olması diğer farklılıkların görünürlüğünü azalttı. Sonuç olarak, ironik bir şekilde, kadınlarla ilişki kurabilmek için erkeklerden referans olmalarını istedim. Benim olduğumu söylediğim kişi olmayabileceğim düşüncesi, kadınları erkeklerden daha çok korkutuyordu sanırım. Bu nedenle olsa gerek, çoğunlukla saygı duydukları bir erkeğin referansı olmadan benimle konuşmaya pek istekli olmuyorlardı.

Benzer şekilde federasyondaki erkekler benim şehit annelerine ulaşmam için referans olmuşlardı. Federasyon'daki şehit babalarına "abi” veya "amca” diye hitap ettim. Türkiye'nin toplumsal yapısı göz önünde bulundurulduğunda, akrabalık terimleri birbirini tanımayan iki yabancı arasındaki ilişkiyi resmiyetten çıkarmaktadır. Resmi bir ilişkiden daha eşitlikçi bir ilişkiye geçebildin. "Bilen insan" olarak kurgulanan araştırmacı halimden aradaki mesafeyi azaltan bir konum elde edebildim. Ancak bu durum yukarıda bahsedilen cinsiyetçi bir yaklaşıma maruz kalmama sebep oldu ve alanda görünmeyen bir “erkek koruması"na sebep oldu. Federasyonun yöneticileri erkek olduğu için erkek ve kadın arasında görülen geleneksel rollere uygun koruma/korunma ilişkisi yarattılar. Böyle hassas bir konuda, kadın olduğum için kandırılabileceğim düşüncesi ile hangi anneler ile ne konuda konuşabileceğimi benim yerime belirlediler. $\mathrm{Bu}$ da alanda şehit annelerine ulaşma konusunda sınırlılıklara neden olmuştu. Bana konuşmam için verdikleri listedeki şehit anneleri sorgulamayan, daha çok babaların veya komutanların (erkeklerin) annelere söyledikleri şeyleri dinleyen ve eleştirmeyen "gerçek" annelerdi. Konuştuklarında, eleştirmek veya şikayet etmek için yapmıyorlardı. Dahası, anlatıları bireysel deneyimlerini içermiyordu. Bunları dernek adına dernekteki erkeklerin yönlendirmeleri ile yapıyorlardı. $\mathrm{Bu}$ nedenle, en baştan alan araştırması yapma nedenime ters düşüyordu. Çalışmamım amacı kadınların kendi deneyimlerini kendi ağızlarından dinlemek ve sesi duyulamayan kadınların sesini duyurmak idi.

Daha sonra kadınlara aracı koymadan ulaşmak için Cuma günleri Cebeci Şehitliğine gittim. Oğullarının mezarları başında dua eden kadınlarla konuşmaya çalıştım. Mezarlıkta kadınlar çoğunlukla yalnız oldukları için kimsenin etkisi altında kalmadan kadınlarla birebir konuşma imkanım olmuştu. Kendimi, neden görüşmek istediğimi anlattım. Şehitlikte konuştuğum kadınlar benimle görüşmeyi kabul etmişlerdi. Ancak ertesi gün randevulaşmak için aradığımda, katılımcılar tekrarlanan çağrılarıma geri dönmediler veya görüşmeyi reddettiler. Nedenini sorduğumda durumlarının özel ve hassas olduğunu bu durumu riske atmak istemediklerini söyleyen de oldu "kocam izin vermedi" diyen de oldu. Her ne kadar bu biraz cesaret kırıcı olduysa da görüşme izni verenler için minnettarım.

$\mathrm{Bu}$ deneyimi kısmen sinir bozucu buldum çünkü güçlü bir şekilde bu sosyal aktörlere ses vermek istiyordum. Ancak alanda karşılaşma zordu çünkü potansiyel görüşmeciler tarafından “öteki” olarak inşa edilmiş gibi hissettim, kadın olmama rağmen, anne değildim. Sonuçta, ben kendini akademik araştırmacı 
olarak sunan genç orta sınıf bekar bir kadındım. Bu zor karşılaşma, araştırmacı konumumun hem müzakere edildiğini hem de inşa edildiğini anlamama yardımcı oldu. En sonunda, kartopu tekniğini kullanarak akrabalarımın tanıdığı bir şehit annesinin bana referans olması ile görüşmecilerime ulaşabildim.

\subsection{Görünmez Pırpırlar}

Alan araştırmamda kendimi asker kızı olarak sunmamın birçok açıdan avantajlı olabileceğini düşünmüştüm. En başta hiç tanımadığım bu grupla birlikte olmanın zorluklarını yaşamak zorunda olmayacaktım ve alandaki insanlarla ilişki kurmamı kolaylaştıracak bir ortaklığımız olacaktı. Bahsi geçen konumsallığımla araştırma yürütmek, avantaj sağlamak bir yana beni zor bir konuma soktu. Hem içerlikli hem de dışarlıklıydım ve buna hiç hazır değildim. Feminist yöntemin bu duruma önerdiği kavram içerideki dışarlıklılar. Wolf (2009) bu durumu şöyle dile getiriyor çeşitli kimlik unsurları ile ortak veya paylaşılan konumlar her zaman araştırmacı ve araştırılan arasında ortak anlayışlar yaratmaz. Başka bir deyişle, araştırmacının içerlikli konumu bazen onu dışarlıklı yapabilir.

Kartopu yöntemi ile ulaştığım annelere ve yakınlarına başlarda asker kızı olduğumu söyledim ancak bir iki görüşmeden sonra fark ettim ki anneler ve yakınları beni askeriyeden gelmiş biri olarak algılamışlar ve kendi deneyimlerini süzgeçten geçirerek aktarıyorlardı. Şehit annesi olmak Gedik'in (2009a) dediği gibi önceden sıradan ev kadınları olan bu kadınlara hem dinen hem de sosyal olarak prestij ve yeni haklar tanıyordu. Özellikle anneler beni askeriyenin onları denetlemek için göndermiş bir araştırmacı sandıklarından oğullarının şehitliğinin lekelenmemesi ve elde ettikleri hakları kaybetmemek için kısa cevaplar veriyorlardı. Bir anlamda, asker kızı konumsallığım alanda bana görünmez pırpırlar (rütbe işaretleri) sağlamıştı. Bu farkındalık, Goffman'ın (2014) “damganın idare edilişi” olarak tanımladığı alan stratejisini kullanmama sebep oldu ve bazı durumlarda asker kızı olduğumu gizledim.

Saha araştırmalarında araştırmacı ile araştırılan arasında güven duygusu kurulması çok önemlidir. Benim gibi hassas gruplarla çalışan araştırmacılar için bu güven duygusu daha önemlidir. Çünkü çalıştığım kadınlar evlat acısı yaşayan kendilerine, ailesine ve çevresine yabancılaşmış, yas içindeki kadınlardı. Benim askeriyeden gelmediğimi veya devlet tarafından gönderilmediğimi belirtmek ve onları buna ikna etmek çok önemliydi. Oğullarının ölümleri ile bu kadınlara sağlanan dini ve sosyal statüyü tehlikeye atacak bir şey yapmayacağım, zaten zor olan hayatlarını daha da zorlaştırmayacağım konusunda bana güvenmelerini sağlamak son derece kritikti. Masanın üzerine bir ses kaydediciyi yerleştirmenin basit eylemi, başka bir insanı odaya getirmek ve sesini "uzağa götürmek" (Kidd ve Finlayson, 2006) imajını yaratmak gibiydi. Bazı görüşmelerde konuşurken yazma eylemi daha güven verici olmuştu. Çünkü "belgeleniyor, kanıt toplanıyor" hissini ortadan kaldırmıştı.

Dahası Wolf (2009) feminist araştırmacılarla ilgili ataerkil normlara direnseler de örneğin, kılık kıyafetlerinde düzenleme, bazı koşullarda bu normlara rıza göstermek zorunda kaldıklarını belirtir. Kadın olmam sempati yaratsa da "araştırmacı" kimliğim ve sol bir etiketle tanınan ODTÜ'den geliyor oluşum beni görüştüğüm kadınlar açısından dışarlıklı bir konuma koyuyordu. Bu nedenle, annelerle görüşmeye giderken giydiklerim konusunda özen gösterdim. Herhangi bir etiketle veya meslekle damgalanmayacak spor ayakkabı, kot pantolon ve göze batmayacak tişörtler seçtim. Yaz aylarında görüşme yapıyor olmama rağmen elbise veya etek ile görüşmelere gitmedim. Feminist yöntemin araştırmanın refleksif olmasına dair yaptığı yoruma bağlı olarak, alanda araştıran ile araştırılan arasındaki ilişkinin tek taraflı olmayacağı anlayışından bu kadınların beni tanımalarına izin verdim.

\subsection{Duygusal, Sınıfsal Karşılaşmalar}

Görüşmeler, paylaşılan deneyimlerdir. Araştırmacılar, görüşmeciler ile katılımcıların hikayelerini anlatmakta kendilerini rahat hissettikleri bir konuşma bağlamı oluşturmak için bir araya gelirler (Ramos, 1989). Corbin et al. (2003) araştırmacılar, travma kurbanları üzerinde araştırma yaparken duygusal durumlarına duyarlı olması ve etik kaygıların farkında olması gerektiğini vurgular. Her ne kadar örneklemimi oğullarının vefatının üzerinden en az bir yıl en fazla beş yıl geçmiş kadınlardan seçmiş olsam da bu kadınlar yukarıda sözü edilen "kutsanmış ve cennet ile ödüllendirilmiş" ölüm algısı nedeni ile yas süreçlerini sonlandıramıyorlardı. Bu nedenle, bu kadınlarla konuşurken yanlış bir tavır takınmaktan gerçekten çok korkuyor, yas içinde olan bir kadına "dışarıdan bakan, sadece soru sormaya gelmiş bir kadın gibi" davranmamak için kendimi hazırlamaya çalışıyordum. 
Yetiştirildiğim ailenin sınıfsal alışkanlıkları alana yansıdı ve ilk görüşmeye giderken babamın önerisi ile şehit annesine bir buket çiçek götürdüm. Ancak görüşmeye gittiğim kadın, Ankara'nın en ücra köşesinde ailesi, ölen oğlunun eşi ve yeni doğmuş torunu ile iki odalı bir gecekonduda yaşıyordu. Elimde koca bir buket çiçekle ilk karşılaşmamız çok tuhaf anlar geçirmemize neden oldu. Çünkü benim gerçekliğim ile şehit annesinin gerçekliği uyuşmamıştı. O hayat içerisinde o çiçekle ne yapacağını bilememişti. O çiçek de benim omuzlarıma kaya oturmuş hissini yaratmıştı. En baştan feminist yöntemin araştıran ile araştırmacı arasında hiyerarşik bir mesafe olmasını ret etmesi anlayışına ters kendi elimle araya sınıftan kaynaklanan mesafe koymuştum.

$\mathrm{Bu}$ karşılaşma bana sonraki çalışmalarım için çok şey öğretti. Alana çıkmadan önce alanı tanımanın önemli olduğunu hatırladım hep. Dahası alan araştırmasının çoğunlukla alanda şekillenen bir araştırma olduğunu deneyimlemiş oldum. Araştırmamın teorik çerçevesini oluştururken araştırdığım onca makale, kitap ve araştırma alanı anlamama sadece kavramsal olarak yardımcı olmuştu. Alanda olmak başlı başına başka bir deneyimdi.

Yıkmış (2015, s. 99) kadın araştırma öznelerinin nasıl konuştukları sorusu ile ilgili şu üç noktayı dile getiriyor "suskunluk, çok katmanlı konuşmalar ve duyguları konuşmak." Kidd ve Finlayson da (2006) hemşirelerle yaptıkları görüşmelerde ortaya çıkan duygusal yoğunlukları incelemişlerdir. Davison (2004) hassas kişilerle çalışan araştırmacıların empati yoluyla aşırı çatışma ve sıkıntı yaşadıklarını dile getirmiştir. Benzer şekilde araştırmam sırasında araştırmacı rolünün etik gerekleri ile katılımcıların ihtiyaçlarına yönelik davranışlar arasında kaldım. Görüşmem, kendimi, araştırmamı tanıttıktan ve demografik sorularımın ardından, kadınların deneyimlerini anlamak adına "oğlunuzun nasıl vefat ettiğini anlatır mısınız?" sorusu ile başlıyordu. Ancak bu soruyu cevaplamak için konuşmaya başladıklarında istisnasız bütün görüşmeci kadınlar ağlamaya başladı. Araştırmaya başlamadan önce, annelerin kendilerini sıkıntılı hissedebileceğinin farkındaydım, onlarla görüşmeye başlayınca etik endişelerim deontolojik bir hal aldı. Annelerle tanıştığımda, hayatlarının samimi detaylarını paylaştıkları için çok heyecanlandım. Ancak, annelerin çoğu anlatısı üzüntü, acı ve öfke gözyaşlarıyla doluydu. Paylaşılan öykülerin içeriğine üzülmüş ve bazen dehşete kapılmıştım. Biraz göz korkutsa da araştırma planıyla ilerlemeye çalıştım. Akademik ve mesleki gelişim arzumla, bireysel olarak annelere acı vermem mümkün mü? Bir yandan anneleri ağlatan kişi olduğum için kötü hissediyor, bir yandan da araştırmaya devam edebilmek için annelerin ağlamasını durdurmaya çalışıyordum. Tüm çalışma boyunca beni en çok strese sokan durum bu olmuştu. Araştırmacı ile araştırılan arasındaki duygusal ilişkiyi incelemek araştırma bulgularına derinlik katabilir. Araştırmacının rahatsızlığın kaynağını ve bu rahatsızlığının etkisini tanımlaması araştırmaya derinlik katmak için bir araç olarak kullanılabilir.

\subsection{Evdeki Erkeklerle Ataerkil Pazarlıklar}

Türkiye'de özel alan kadınların alanı olarak görülür. Kadınlar bir eş ve anne olarak özel alanda bir miktar kontrol sahibi olabiliyorlar. Başka bir deyişle, Deniz Kandiyoti'nin kavramsallaştırmasıyla özel alanda, hane içinde ataerkil pazarlıklar yapabiliyorlar. Bu nedenle, annelerin kendilerini rahat hissetmeleri için evlerinde yalnız görüştüm. Ancak çoğu zaman ailenin diğer üyeleri, özellikle erkekler, evin bir araştırma alanı olmasına itiraz ettiler. Görüşmeye katılanların oğullarından biri sürekli olarak odaya girdi, çoğu zaman bahane annesi adına konuşmak idi, annesinin yaşlı olduğu, yasta olduğu için konuşmayı istediğini belirtti. Ailenin erkek üyeleri hem katılımcı hem de araştırmacı üzerinde yetki kurmaya çalıştırlar. "Arendell, erkek görüşmecilerin hangi soruların nasıl sorulması gerektiğinden kayıt cihazının nereye konulması gerektiğine kadar kendisini yönlendirmeye çalıştıklarını belirtir ve kadınlarla yaptıkları çalışmalarda bu tür davranışlarla karşılaşmadığını da vurgular" (aktaran Körükmez, 2016, s. 64). Bu nedenle saha çalışması sırasında ortaya çıkan cinsiyet riskleri sadece benim bir kadın, bir yabancı ya da bir araştırmacı olmam veya bunların hepsi aynı anda evin erkeklerini rahatsız etmişti.

Konyar (2016, s. 184) saha araştırmalarını şu şekilde betimler

Etnografik çalışmaların önemli bir boyutunu oluşturan saha çalışması, araştırmacının çalışmayı düzgün bir şekilde yürütebilmesi için sadece kuramsal bilgilere sahip olmasının yanı sıra pratik bilgileri de gerekli kılar. Araştırmacı saha çalışmasında, verileri sağlam bir şekilde elde etmeye çalışırken hesap etmediği pek çok öznel durumlarla karşı karşıya kalabilir.

$\mathrm{Bu}$ açıdan, çalışma alanım, çalıştığım yıl için daha önce Türkiye'de hiç çalışılmamış bir alandı. Bu nedenle alanda neler ile karşılaşabileceğime dair elimde örnek çalışmalar yoktu. Ancak saha çalışması yaparken deneyimlerim bir sonraki görüşmeye beni yeniden hazırladı. Çalışmayı yürüttüğüm dönemde kendilerine "Barış Anneleri” diyen bir grup kadının şehit annelerinin evine gelip, terör propagandası yaptığına 
dair birkaç gazete haberi çıkmıştı. Türkiye'de kadınların kamusal alanı ve siyaseti takip etme olanağı ve deneyimleri düşünüldüğünde, yas içinde olan annelerin bu haberlere dair bilgisi yoktu. Ancak evdeki erkeklerin şehit annesi olarak yeniden tanımlanan, özel ve kamusal alanda statüleri olan bu kadınların sahip oldukları bu statünün sağladığı saygınlık ve haklar adına kadınları daha önce görece özgür oldukları özel alanda da kontrol altına aldıklarını gördüm. Bazı feministlere göre nötr dil diye bir şey yoktur: "Erkeklere ait olduğu ve erkekler tarafından kontrol edildiği için tüm sistem, baştan sona cinsiyetçilik ile iç içe geçmiştir” (Cameron, 1985, s. 91). Gerçekliğin dil yoluyla inşa edildiğine dair inanç, birçok feminist literatürün, dilin kontrolü yoluyla kadınların 'susturulması' üzerine odaklandığını açıklar. Bu anlamda bahsi geçen haberler hakkında bilgileri olan erkekler vardı ve bazı görüşmeler sırasında evde kadınları yalnız bırakmayan bu erkekler "çözüm ve barış hakkında ne düşünüyorsunuz?" sorusuna anneler yerine konuştular ve sert tepkiler verdiler. Hatta zaman zaman beni terörist olmakla suçlayıp evden uzaklaştırdılar.

\section{Sonuç}

Üç dönem verdiğim Saha Çalışmaları dersi sırasında kendi tez çalışmalarımın saha deneyimlerinden verdiğim örneklerin, öğrencilerin dersi ve saha çalışmasını, özellikle kadın olarak sahada bulunmanın ne demek olduğunu, anlamalarına daha yardımcı olduğunu gördüm. Bunun sonucu olarak, saha çalışmalarım sırasında karşılaştığım sorunları ve deneyimleri sistematik bir şekilde ve saha çalışması teorilerini baz alarak yazdım. Bu çalışma kapsamında özellikle daha önce saha deneyimi olmamış araştırmacıların hassas gruplarla çalışmaya karar verdiklerinde karşılaşabilecekleri unsurları belirttim. Bunların en başında araştırmacı ile araştırılan arasında güven ilişkisi kurmanın öneminden bahsettim. Dahası feminist bir yöntem uygulayan kadın bir araştırmacı olarak erkek görüşmecilerle çalışmanın yaşattığı ikilemleri ifade etmeye çalıştım. Yukarıda da bahsettiğim gibi feminist yöntem saha araştırmasındaki güç dengelerini yok etmeye ve araştıran ile araştırılan arasındaki hiyerarşiyi ortadan kaldırmayı amaçlar. Ancak erkeklerle yapılan görüşmelerde toplumdaki ataerkil ilişkilerin bir yansıması olarak saha çalışması sırasında toplumsal cinsiyet rollerinin çarpıştığını anlattım. Artı, saha çalışmaları sırasında alanı bulmanın zorluklarından ve bu konuda araştırmacının konumsallığının rolünü anlattım. Bu açıdan saha araştırmaları teorilerinde de bahsedildiği gibi "içerlikli” ve "dışarlıklı" konumlarının sabit olmadığı ve bazen içerlikli dışarlıklı olunabileceğini gösterdim. Araştırmacının alana ulaşması sırasında özellikle var olan damgaları ile nasıl mücadele edebileceğini ve görüşmecilerle ilişkisine bu damgaların etkisini nasıl zayıflatabileceğini tartıştım. Bu amaçla, başta kılık kıyafet olmak üzere sınıfsal, ideolojik veya herhangi bir dini hatırlatabilecek aksesuarları kullanmamanın önemini açıkladım. 
${ }^{1}$ Şehit annesi terimini sınıflandırma yapmak için kullanıyorum. Şehit kavramı pek çok insanı vurgulamak için kullanıldığından, bu araştırmada şehit kavramını Türk Silahlı Kuvvetlerinde askerlik görevini yaparken ölen askerler için kullanıorum.

${ }^{2}$ Bu konu ile ilgili başka çalışmalar için bakınız: Sancar, 2001; Gedik, 2009a; Gedik, $2009 b$.

${ }^{3}$ Bahsi geçen haklar ve annelerin yaşadığı durum hakkında ayrıntılı bilgi için bakınız: Gedik, $2009 \mathrm{~b}$.

${ }^{4}$ Şehit anneleri ve şehit babalarının siyasete katılımı konusunda bir araştırma için bakınız: Gedik, $2009 \mathrm{~b}$.

\section{Kaynakça}

Arendell, T. (1997). Reflections on the researcher-researched relationship: A woman interviewing men. Qualitative sociology, 20(3), 341-368.

Aslan, Ö. (2008). “Kaçınılmaz Ölüm” Ün Girdabında Annelik. Kültür ve Siyasette Feminist Yaklaşımlar, Sayı 5.

Brooks, A., \& Hesse-Biber, S. N. (2007). An invitation to feminist research.Feminist research practice: A primer, 1-24.

Cameron, D. (1985). Making Changes: Can We Decontaminate Sexist Language?. In Feminism and linguistic theory (pp. 72-90). Palgrave Macmillan, London.

Cook, J. and Fonow, M. M. (2007). Knowledge and Women's Interests: Issues of Epistemology and Methodology in Feminist Sociological Research. Sociological Inquiry, 56(1), 2-29.

Corbin, J., \& Morse, J. M. (2003). The unstructured interactive interview: Issues of reciprocity and risks when dealing with sensitive topics. Qualitative inquiry, 9(3), 335-354.

Davies, C. A. (2008). Reflexive Ethnography. A Guide to researching selves and others. (London ve New York: Routledge).

Davison, J. (2004). Dilemmas in research: Issues of vulnerability and disempowerment for the social worker/researcher. Journal of Social Work Practice, 18(3), 379-393.

Fonow, M. M., \& Cook, J. A. (Eds.). (1991). Beyond methodology: Feminist scholarship as lived research. Indiana University Press.

Gedik, E. (2009a). Türkiye'de Şehit Annelerinin Savaş ve Çözüm Algıları. Fe-Dergi: : Feminist Eleştiri Cilt 1 Sayı 2 , ss. 29-44.

Gedik, E. (2009b). Savaşın Geride Bıraktıkları, Anneler. Amargi, sayı 15.

Goffman, E., \& Ağırnaslı, S. N. (2014). Damga: örselenmiş kimliğin idare edilişi üzerine notlar. Heretik Yayıncılık.

Gurney, J. N. (1985). Not one of the guys: The female researcher in a male-dominated setting. Qualitative sociology, 8(1), 42-62.

Harding, S. G. (Ed.). (1987). Feminism and methodology: Social science issues. Indiana University Press.

Hesse-Biber, S. N. (Ed.). (2007). Handbook of feminist research: Theory and praxis. Sage.

Hesse-Biber, Sharlene (2011). Emergent Technologies in Social Research: Pushing Against the Boundaries of Research Praxis. PP. 3-22. In. Sharlene Hesse-Biber, Editor. Handbook of Emergent Technologies in Social Research. New York: Oxford University Press.

Hollway, W., \& Jefferson, T. (2000). Doing qualitative research differently: Free association, narrative and the interview method. Sage.

Konyar, H. (2016). Etnografik Çalışmanın Saha Çalışması Notları:“Katılımcı Yurttaş Kimliğinin Kurulması Ekseninde Yemek Yeme ve Bedenin Yeniden Üretim Pratikleri: İstanbul'da Etnografik Bir Alan Çalışması”. Akdeniz Üniversitesi İletişim Fakültesi Dergisi, (26), 181-192.

Kidd, J., \& Finlayson, M. (2006). Navigating uncharted water: Research ethics and emotional engagement in human inquiry. Journal of psychiatric and mental health nursing, 13(4), 423-428.

Krilić, S. (2011). "The Role of Ethnicity in Qualitative Migration Research" Migracijske i etničke teme 27, 2, $161-175$.

Körükmez, L. (2006). “Kadın Araştırmacıların Erkek-Dominant Sahada Çalışması Mümkün mü?” Fe Dergi 8, no. 2, $62-72$.

Landman, M. (2006). Getting quality in qualitative research: A short introduction to feminist methodology and methods. Proceedings of the Nutrition Society, 65(04), 429-433.

Lee, R. M., \& Renzetti, C. M. (1990). The problems of researching sensitive topics: An overview and introduction.

McCorkel, J. A., \& Myers, K. (2003). What difference does difference make? Position and privilege in the field. Qualitative sociology, 26(2), 199-231. 
Naples, N. A. (2007). Feminist Methodology and Its Discontents. In W. Outhwaite ve S. P. Turner (eds). The Sage Handbook of Social Science Methodology, Los Angeles: Sage Publications.

Narayan, K. 1993. How native is a 'native anthropologist?'. American Anthropologist, 95: 671-685.

Oakley, A. (1981). Interviewing women: a contradiction in terms. In Helen Roberts (Ed.), Doing feminist research (3062). London: Routledge \& Kegan Paul.

Oğuz, H. Ş. (2012). Alanda Bir Kadın. Fe Dergi 4 (1), 64-80.

Ramazanoğlu, C. ve Holland, J. (2002). Feminist Methodology: Challenges and Choices. London, New Delhi: Sage Publications.

Ramos, M. C. (1989). Some ethical implications of qualitative research. Research in Nursing \& Health, 12(1), 57-63.

Sancar, S. (2001). "Savaşta Çocuklarını Kaybetmiş Türk ve Kürt Anneler”, Toplum ve Bilim, sayı 90, ss. 22-41.

Sara Ruddick. "Maternal Thinking”. Feminist Studies 6. 2. (Yaz 1980).

Scheper-Hughes, N. (2008). Anneliğe Özgü Düşünme Biçimi Ve Savaş Politikaları. Kültür ve Siyasette Feminist Yaklaşımlar, Sayı 5.

Wolf, Diane L. "Saha Çalışmasında Feminist İkilemler," Methodos: Kuram ve Yöntem Kenarından ed. Dilek Hattatoğlu ve Gökçen Ertuğrul (İstanbul: Anahtar Kitaplar, 2009), 372 - 442.

Yıkmış, M. S. (2015). Kadınlarla mülakat yapmak. Fe Dergi, 7(1), 95-107. 